\title{
Timotheus Polus and Reiner Brockmann: \\ the Nexus between the Estonian and \\ European literary discourse
}

\section{Introduction}

The early $17^{\text {th }}$ century has been considered the beginning of secular literature in Estonia. It was mainly written in Latin and in German, taking into account the tradition and the principles of Baroque literature. Concurrently, the first Estonian-language literary works were composed. The earliest example of Estonian-language poetry dates back to 1637 . In other words, in the period between the $17^{\text {th }}$ and the $19^{\text {th }}$ century in Estonia, more than one intertwined literary tradition arose at the same time. The Estonian literary field during that period can be interpreted as a multilingual constellation, which is based on different writing traditions (such as city literature, religious poetry, etc.) (Lukas 2008: 23-32)

However, in analyzing different versions of the history of Estonian literature by various authors, we come to realize that the concept of "Estonian Literature" has somehow always been linked to the Estonian language. This has been criticized by Jaan Undusk, who considered the scholarship of Estonian literary history lopsided. According to Undusk, when researching Estonian literature regarding only the Estonian-language part of it we forget that the linguistic constellation in this country has always been bi- or even multilingual. The cultural processes, which led to the formation of Estonian literature and culture, cannot be interpreted from the monolingual point of view. Hence, Undusk supports the idea of large-scale studies of Estonian-language literature (Undusk 2003: 1495-1496).

As a matter of fact, in 1965 Otto Webermann, German literary scholar, spoke about the necessity to regard Estonian literature as an integral whole. On the one hand, there had been a number of Baltic-German authors, who wrote literature in German as well as in Estonian. On the other hand, there were several authors, who never wrote a single text in the Estonian language, but,

\footnotetext{
1 The article was written with the support of the research projects of Estonian Science Foundation (grants 7824 and 8304)
} 
nevertheless, delivered an important contribution to the development of Estonian language and culture. According to Webermann, the scholarship of Estonian literature should be balanced and include both Estonian and German cultural fields (Webermann 1965: 221).

Meanwhile, the literature of the Baltic-German upper-class can be considered a part of the Estonian literary canon, at least among scholars. However, there are still some relatively undiscovered periods in the history of literature in Estonia, especially at its dawn in the early $17^{\text {th }}$ century.

In the present article I will try to find some balance in this respect and present two authors, belonging to this early period - Reiner Brockmann and Timotheus Polus. Both of them were born in Germany, both of them came to Tallinn/Reval to fill a position as a professor at Reval Gymnasium, founded in 1631 (see Klöker 2005 I: 275-294 and 300-314).

The literary life in Tallinn of the $17^{\text {th }}$ century was centered around the professors at the gymnasium, which might have been due to the tradition of the humanistic era (Klöker 1998: 840) or the inspiring impact of the poetry-loving environment (Lepajõe 2009a: 19). However, relatively soon after its foundation, the Tallinn Gymnasium began publishing occasional poems of the professors, written in Latin, as well as in German. The explosive increase in writing German-language poetry in the first half of the $17^{\text {th }}$ century is usually associated with the influence of Martin Opitz (1597-1639). The success of his practical poetry manual Buch von der Deutschen Poeterey ("Book of German Poetry") (1624), and the impact on both contemporary and later German poetry, is considerable. However, it is uncertain, whether Opitz's book would have found such acclaim if it had not corresponded to deeper tendencies in German educational life, characterized by Wolfgang Ratke's (1571-1635) innovative reform plans. These aimed to make schools change to Germanlanguage teaching and to use the mother tongue (ib. 19). Consequently, both Polus and Brockmann can be seen as open-minded professors of the modern era. In addition to that, both of them had written a number of high-quality poems in Latin as well as in German. It should be mentioned, that Brockmann is also known as the trailblazer of Estonian poetry: he was the author of the first Estonian-language poem, Carmen Alexandrinum Esthonicum. "As a superb linguist, Brockmann immediately took an interest in the Estonian language, going to church to listen to sermons in Estonian. Three years later, he was already able to produce prose translations of hymns, and also write poetry, in Estonian.” (Ib. 19) 
HEERO

Timotheus Polus was also very active in the literary field in Estonia. He introduced the Book of German Poetry by Martin Opitz and initiated the "German Turn" in the local field of cultural production in Reval, which had been dominated by Latin until then (Klöker 1993: 132; Viiding 2008: 153). Moreover, he was definitely interested in Estonian history and culture and often referred to it in his works. In other words, Polus's and Brockmann's activity built a connection between German and Estonian literature (even though it was written in German).

\section{Timotheus Polus (1599-1642)}

Timotheus Polus did not write any poems in the Estonian language, but this does not mean that he disregarded the local life in Estonia. On the contrary: many texts of Polus himself and of his friends and colleagues reveal his interest in Estonian history and culture.

To illustrate this, an example of the famous German poet Paul Fleming (1609-1640) will be discussed. Fleming, who belonged to the embassy of Friedrich III, the Duke of Holstein-Gottorp, came to Reval together with the other oriental travelers of the embassy. After his arrival at Reval (in 1635), Fleming established close ties with several scholars at the gymnasium, especially with Polus and Brockmann. In the same year Fleming wrote a long pastoral poem for the wedding of Reiner Brockmann and Dorothea Temme. In this very bucolic text, many well-known individuals of Reval appear as shepherds, including Polus and Brockmann. In the case of Polus, Fleming describes him as an advocate of his new home in Reval. For example, when one of his opponents argues, that the geographical location of Estonia and Livonia is very unfavorable because of its close proximity to the "barbarians", which affects its cultural life negatively, Polus says: "If Livonia hadn't had those hundred years of grievous wars with its neighbors, it would be prosperous and all the arts would bloom here even better than in Germany." (Fleming 1986: 27) Of course, the figure of Polus in Fleming's poem is fictional, but in many of his texts Polus presents himself as representative of Estonian culture. This will be explained by looking at several poems, written by Polus.

In 1637 a very important book for Estonian culture, Heinrich Stahl's Introduction to Estonian Language was published. In this work, two poetical dedications by Timotheus Polus form a preface to Stahl's explanations about the Estonian grammar. In the first poem, Polus congratulates Stahl on the

publication of the book and recognizes his contributions to the education in 
Estonia. First, Polus gives honorable mentions to Stahl's translations from German into Estonian: "What Luther has done for his language and therefore for his whole country, now you, Mr. Stahl have done for the language of Estonians.” (Stahl 1637) Polus refers here to Estonian-language catechism, translated by Stahl and published in 1632, which includes the Small Catechism of Luther, some church chorals and excerpts from the New Testament.

In the introduction to his book, Stahl emphasizes the importance of cultural transfer. The parsons, according to Stahl, had not had a proper Estonian compendium before, which is why they were not able to spread the Word of God among the Estonian peasants, who were left behind to the darkness of ignorance (Stahl 1632). Although the transfer of Lutheran culture to the Estonians is vital, it seems to be more important to Polus, that German scholars have the possibility to study the Estonian language, to learn more about Estonian culture and to enrich their intellect.

In the second poem, Polus introduces several famous European scholars like Ronsard, Plautus, Caesar, Luther and others, who made an important contribution to the development of their native languages. According to Polus, Heinrich Stahl should be one of those men, because he had elevated the Estonian language to its rightful place among the languages of the civilized world: "You will be praised forever, Mr. Stahl, because you made it possible for Estonians, to learn the Word of God in their country and in their own mother tongue." (Stahl 1637)

Another example will show us, how Polus defines himself as a representative of Estonian culture (even though it is German culture in Estonia). In 1639 Polus published his book entitled Lustiger Schawplatz ("The Merry Showplace”), which was compiled from various lexicons. In this book, Polus introduces persons, institutions, professions, arts, industries etc in a rather entertaining way. His main source was Tomaso Garzoni's book Piazza universale (published in 1585), in which several arts, professions, status groups, virtues and vices were presented. Garzoni's work spread over all of Europe very quickly; however, in Germany it was more popular than in other countries. Between 1619 and 1659 four German translations of Garzoni's book were published in Germany (Battafarano 1991: 112). Polus, who used Garzoni's texts for his own publication, was surely aware of the popularity of Piazza universale and his book has been, without any doubt, a part of a trans-European trend.

In comparing these two publications, Lustiger Schawplatz and Piazza universale, it is evident that Polus did not translate all chapters and he also 
HEERO

shortened the original texts of Garzoni, which was quite common at the time. One of the other translators of Garzoni's work, Albertinus, who translated Piazza universale into German in 1636, left out whole chapters about witches and whores (ib. 113).

Furthermore, Polus integrates a reference to local circumstances in many of his own texts. At the beginning of the chapter, entitled Academies, Polus gives a brief overview about the history of the term "academy", after which he introduces several academies, like Garzoni did. Next, Polus dwells on a special academy: "Under academies, established by kings and emperors, there is an excellent one, founded by His Majesty King of Sweden, Gustav Adolph, in Dorpat some years ago [in 1632].” (Polus 1639a: 11) However, at this point Garzoni praises not the University of Dorpat/Tartu but the Academy of Pavia: "Under our Italian academies the most exclusive one is the Academy of Pavia." (Garzoni 1641: 187)

Another interesting chapter in Lustiger Schawplatz, called The Germans, describes the earlier periods of German history and the Christianization of German tribes. Remarkably, Polus has added a little paragraph about the history of Livonia in this chapter: "In 1186, a very religious man, named Meynardus, began to spread the Word of God in Livonia. He founded a diocese near Riga, but there was also a great resistance to it, until many people came there as crusaders and forced the Livonians to Christianity." (Polus 1639a: 125) In this particular chapter, Polus sees the history of Livonia as it was known then, as a part of German history, and, in this way, a part of world history.

Polus not only describes Estonian history in his texts but also gives various small hints about the local topography. The main focus of his poem for the wedding of Georg Saleman and Gertrud Wiebe lies in the description of the deep grief of the groom after losing his first wife and in the healing of his wounded heart. Polus colorfully depicts how the grieving widower wanders around in the city of Reval, searching for some kind of medicine to cure his mind of sorrows. Eventually, falling in love again will heal his pain. Describing Saleman's journey throughout the city, Polus subtly alludes to several locations, e.g. "Looking from your home, there were certain institutions left and right. On the right, there was a barber [In Reval, the barbers were allowed to practice as a surgeon - A. H.]. On the left, there was a pharmacy, which was always open.” (Polus 1639b) But no help can be found at those locations. After visiting the pharmacy, the widower goes to the marketplace, which is, according to Polus, "not far from your backdoor" (ib.) but there he cannot find anything to cure 
himself, either. What does it mean? Georg Saleman was the parson of the Church of the Holy Spirit. When one stands facing the altar in this church, on the left is the Town Hall Pharmacy. The Town Hall Square, also known as New Market, is really not far from the northern door of the church. In other words, Polus tells us the love-story with a happy ending; at the same time, this common narrative takes place in an existing city, which can be identified easily. In several other poems, Polus uses the same method to connect universal stories with the local history. It means, he elucidates not only the topography of the city of Reval, but also his own current situation (for example the relationships with his friends). This quite personal writing style is rather uncommon for the Baroque era, which postulates a general tendency for classification and intertextuality and the usual approach to human nature was determined by religion (Heero 2009: 41-42).

Finally, Polus' poem To My Highly Honored Mr. Fleming should be mentioned. It was written in 1639 and dedicated to Paul Fleming's return from his long journey to Persia. The poem itself is relatively short (only four stanzas) and it mainly praises Fleming's poetical skills and the beauty of his texts. However, there is one very interesting line in this poem, in which Polus welcomes Fleming to his "fatherland" (quoted in Fleming 1641 II: 625). On the one hand, Polus may be alluding to Fleming's wish to settle down in Reval, but on the other hand, this line can be interpreted as Polus's vision about Reval as a part of the whole German-speaking cultural region. When reading Fleming's poems he had written while he was away in Persia, we come to see, that Fleming understands the term "fatherland" to mean the cultural area of Germany and Europe (see Pohl 1993: 300-301). This fact supports the second hypothesis. Polus's poem, which almost reflects the modern European idea of shared cultural space, demonstrates, that the author is thinking not only in his local context, but he is also able to broaden his horizons and to see his own personal history as part of a much larger global picture (Heero 2010: 468).

\section{Reiner Brockmann (1609-1647)}

Brockmann's poetry is characterized especially by its great variety. Like Polus, he was aware of Opitz' poetical rules, presented in the Book of German Poetry (1624) and, obviously, inspired by them. He also used several poetical forms, such as the alexandrine, sonnet or ode, which are presented in Opitz' book. Another feature, common to both Polus and Brockmann is that they comment to their present surroundings. However, while Polus gives hints about the local 
topography quite vaguely, Brockmann clearly presents his point of view about the political situation in Germany as well in Estonia and Livonia. In a nuptial poem, for example, he describes Reval as an idyllic place, in contrast to Germany, which is war-torn and destroyed (Brockmann 1638).

In addition to this, Brockmann wrote poems not only in Latin, Greek and German, but also in Estonian, which is quite remarkable for the early $17^{\text {th }}$ century. While Polus was merely talking about the importance of studying Estonian (for example in the poem dedicated to Stahl), Brockmann actually learned the Estonian language. Lepajõe points out, that the "trend towards use of the mother tongue inevitably led to attempts to write verse in Estonian, (...). This was obvious from contemporary descriptions about the dismal conditions in which Estonian peasants lived, as well as in Brockmann's own correspondence (...)." (Lepajõe 2009a: 20)

Brockmanns knowledge of Estonian can be seen in many of his poems. For example in the sonnet for the wedding of Gebhardt Himsel and Brigitta von Schoten, he uses Estonian words to mark the circumstances, which are rooted in rural culture. He wrote: "What a sweet joy in the lovely summertime / Is all over in Livonia, when one is participating in the Talckus." (Brockmann 2000: 89) In Estonian "Talckus" means the collective work on a certain day, followed by the treat for successful accomplishment of the task. This is a tradition, which was probably unusual in Germany but very common in Estonia.

Brockmann's interest in Estonian culminates in his five Estonian-language poems, which define the beginning of Estonian literature (see also Lepajõe 2009a: 20). Hence, Brockmann's poem with the title Carmen Alexandrinum Esthonicum ad leges Opitij poëticas compositum (that is, the adaptation of Opitz' rules to Estonian language) can be read as a manifesto, in which the author considers himself as the trailblazer of the Estonian poetry.

The title Carmen Alexandrinum Esthonicum ad leges Opitij poëticas compositum refers to the Book of German Poetry by Martin Opitz, in which the author commends the beauty of German language amongst other things. According to Opitz, the German language is very suitable for writing poetry as demonstrated by its illustrious tradition of heroic poems. However, writing good poetry means knowing the correct poetical rules. Hence, Brockmann combines two traditions in his Estonian-language poem. On the one hand, he demonstrates that one is capable of writing high-qualified poetry in Estonian, providing that he has a knowledge of poetic techniques as well writing skills. Of course, at the same time Brockmann's poem proves the efficiency of Opitz' poetic rules - they can be used in German as well as in Estonian. On the other 
hand, Brockmann values Estonian as the literary language in his poem considering it a language of the civilized world, even though the tradition of Estonian literature does not exist yet. Within his Estonian-language poem, Brockmann attempts to change this perception sees himself as the initiator of literary tradition in Estonia (Lepajõe 2009b, 772).

Concerning the topic of this poem, it is a traditional nuptial poem, which praises the integrity of the bridegroom, the beauty of the bride, the wealth of the father of the bride and the nobility of the guests (see Brockmann 2000: 9394). At this point, Brockmann's eloquence should be emphasized. The fluency of all 42 lines is remarkable as well as the clarity of the rhymes. Certainly, it is not a thoughtlessly drafted text but a result of a long and careful learning process. Even more, it is proof that it is possible to write high-quality poems in Estonian. Possibly, Brockmann even intended to create a number of Estonian poems, using all the poetical forms, described by Opitz, because he had entitled all his Estonian-language poems with a reference to the Opitz' book (such as Oda Esthonica Trochaica or Oda Esthonica Jambico-Trochaica).

Another poem, entitled Lectori Carminis Esthonici presents Brockmann's opinion about Estonian language very clearly. The text begins with a strong statement: "Others may want to do it a different way / But I wanted to write in Estonian." (Brockmann 2000: 94) Hereby, Brockmann possibly refers to the Carmina of Horace, in which the motif of "doing it another way" is widely used (Lepajõe 2003: 331f). The following lines state this argument more precisely. At first, Brockmann illustrates the widespread knowledge of Estonian language among all strata of society: "Estonian is spoken in the countryside / Estonian is spoken on the beach / Estonian is spoken between the city walls / Estonian is spoken also by the peasants / The noblemen speak Estonian / The scholars speak Estonian / The ladies speak Estonian / And also those people, who came from Germany / Young and elderly people speak Estonian /" (Brockmann 2000: 95). Next, Brockmann emphasizes the fact, that Estonian is used in the churches and the Word of God can be spread in Estonian as well. In this instance, Brockmann may be alluding to himself. As we know, he translated a number of religious texts into Estonian and he has been influential in the development of Estonian language and literature. Although Brockmann does not mention his own name explicitly, this allusion can be read as a compliment to himself. Then, Brockmann refers to the Greek mythology. He mentions the "Pierinnen" (Pierides) (ib.), that is, the nine young ladies, who challenged the Muses to a singing competition and who were turned into magpies on their defeat. However, Brockmann speaks about "wise Pierides", who will "love 
Estonian" (ib.) - and, probably, will not be defeated any more because of using this language. This is a rather intriguing metaphor. It is possible that Brockmann considers the knowledge of Estonian as a very useful skill and great advantage. And, as we know, learning Estonian was a real benefit in Brockmann's professional career. The last two lines repeat the first statement: "I wanted to write in Estonian / Others may do it another way." (ib.)

Both poems, Carmen Alexandrinum Esthonicum and Lectori Carminis Esthonici must be regarded as a small cycle, which begins with the Estonianlanguage poem, followed by the author's explanation of why he wrote in Estonian. Of course, Brockmann exaggerates when describing Estonian as a global language; he must have been aware, that there was no hope of finding many readers who could enjoy his Estonian-language writings. However, Brockmann's allusions to himself and to the "wise Pierides" show us that learning Estonian had become more important, at least among churchmen. Moreover, Brockmann's Estonian-language poems proved to the audience at that time, that it is possible to write high-quality texts in Estonian, which created the prerequisites for the formation of the Estonian literature.

\section{Conclusion}

Certainly, there is the question whether Polus and Brockmann are Estonian writers. Although their Estonian-language oeuvre is rather small (in case of Polus even non-existent), both of them were definitely interested in the Estonian language, history and culture, as I have shown with various examples. Besides, both Polus and Brockmann acted at the beginning of a new literary era in a multilingual space, in which the use of more than one language is standard. Therefore, we may define Polus and Brockmann as two writers with double identities, whose texts link the literatures in Estonia and in Western Europe. Considered in this light, at its dawn, Estonian literature was very close to the canon of world literature.

\section{References}

Battafarano, I. M. 1991. Vom polyhistorischen Traktat zur satirischen Romanfiktion. Garzonis Piazza Universale bei Albertinus und Grimmelshausen. - Battafarano, I. M. (ed.), Polyhistorismus und Interkulturalität in der Frühen Neuzeit/ Tomaso Garzoni. Bern / Berlin / Frankfurt a.M.: Peter Lang, 109-124.

Brockmann, R. 1638. Liebes Revall / deine Freunde. Nuptial poem for Meuseler and Müller. Reval: Reusner. 
Timotheus Polus and Reiner Brockmann

Brockmann, R. 2000. Teosed. Ed. by E. Priidel. Tartu: Ilmamaa.

Fleming, P. 1865. Deutsche Gedichte. Vol. I-II. Stuttgart: Literarischer Verein.

Fleming, P. 1986. Gedichte Auff des Ehrnvesten und Wohlgelahrten Herrn Reineri Brockmans / der Griechischen Sprache Professorn am Gymnasio zu Revall / Und der Erbarn / Viel-Ehren und Tugendreichen Jungfrawen Dorotheen Temme / Hochzeit. Meid, V. (ed.), Paul Fleming. Deutsche Gedichte. Stuttgart: Reclam, 10-38.

Garzoni, T. 1641. PIAZZa Universale (...) Zu Franckfurt am Mayn / In Wolffgang Hoffmans Buchdruckerey / In Verlag Matthæi Meriani.

Heero, A. 2009. Deutschsprachiges Gelegenheitsschrifttum in Reval am Beispiel von Timoteus Polus' Hochzeitsgedichten in der Sammlung Vota nuptialia. - Tarvas, M. (ed.), Autobiografisches Schreiben von der Frühen Neuzeit bis in die Gegenwart. Frankfurt a.M.: Peter Lang, 29-50.

Heero, A. 2010. Weiße Flecken in der estnischen Literaturgeschichtsschreibung. Timoteus Polus und der Revaler Gymnasialkreis. - Interlitteraria 15/2, 457-471.

Klöker, M. 1993. Reiner Brockmann und der Revaler Dichter- und Gelehrtenkreis im frühen 17. Jahrhundert. Magisterarbeit. Universität Osnabrück.

Klöker, M. 1998. Literarische Kultur in Reval in der ersten Hälfte des 17. Jahrhunderts. Garber, K. (ed.), Stadt und Literatur im deutschen Sprachraum der Frühen Neuzeit. Vol. III. Tübingen: Niemeyer, 822-842.

Klöker, M. 2005 I-II. Literarisches Leben in Reval in der ersten Hälfte des 17. Jahrhunderts (1600-1657). Institutionen der Gelehrsamkeit und Dichten bei Gelegenheit. Vol. I: Darstellung. Vol. II: Bibliographie der Revaler Literatur. Drucke von den Anfängen bis 1657. Tübingen: Max Niemeyer Verlag.

Lepajõe, M. 2003. Reiner Brockmann und die Anfänge der estnischen Kunstpoesie. Garber, K., Klöker, M. (eds.), Kulturgeschichte der baltischen Länder in der Frühen Neuzeit. Mit einem Ausblick in die Moderne. Tübingen: Niemeyer, 319-335.

Lepajõe, M. 2009a. Reiner Brockmann: Ich hab wollen Esthnisch schreiben. I wanted to write in Estonian. - Estonian Literary Magazine, 29, 16-21.

Lepajõe, M. 2009b. Reiner Brockmanni värsside vältimatusest. - Keel ja Kirjandus, 10, 758776.

Lukas, L. 2008. Balti kirjakultuuri mitmekeelsest loomusest. - R. Undusk (ed.), Rahvuskultuur ja tema teised. Tallinn: Underi ja Tuglase Kirjanduskeskus, 23-33.

Pohl, M.C. 1993. Paul Fleming. Ich-Darstellung, Übersetzungen, Reisegedichte. Münster/ Hamburg: Lit Verlag.

Polus, T. 1639a. G. Lustiger Schawplatz (... ). Gedruckt zu Jena bey Ernst Steinmann / In Verlegung Martini Janovii Buchhändler in Lübeck.

Polus, T. 1639b. Brautlied / Dem Ehrwürdigen / Andächtigen / vnd Wohlgelahrten H. Georgen Saleman (...). Revall / Gedruckt bey Heinrich Westphal / Gymnasij Typographo. Reval: Westphal.

Stahl, H. 1632. Hand und Hauszbuches Für die Pfarherren, und Hauszväter Ehstnischen Fürstenthumbs Erster Theil (...). Gedruckt zu Riga, durch Gerhard Schröder.

Stahl, H. 1637. Anführung zu der Esthnischen Sprach, auff Wolgemeinten Rath, und Bittliches Ersuchen, publiciret von M. HENRICO Stahlen. Revall, Druckts Chr. Reusner der älter, in Verlegung des Authoris. M.DC.XXXVII. Tristfer: H. Stahl (Reval: C. Reusner). 
HEERO

Undusk, J. 2003. Scaliger ja Opitz: juhuluule uurimine uuele tasemele. K. Viiding: Die Dichtung neulateinischer Propemptika an der Academia Gustaviana (Dorpatensis) in den Jahren 1632-1656. Tartu: Tartu University Press, 2002. - Akadeemia 7 (15), 14951506.

Viiding, K. 2008. The literary background of early Estonian secular writing: the current situation and future perspectives in research. - Ross, K., Vanags, P. (eds.), Common roots of the Latvian and Estonian literary languages. Frankfurt a.M.: Peter Lang, 147-163.

Webermann, O. A. 1965. Zum Problem der Gelegenheitsdichtung. - Kõressaar, V., Rannit, A. (eds.), Estonian Poetry and Language. Studies in Honor of Ants Oras. Stockholm: Vaba Eesti, 218-233. 